\title{
Volatile Versus Intravenous Anesthetics in Cardiac Anesthesia: a Narrative Review
}

\author{
Christopher Uhlig ${ }^{1}$ (D) Jakob Labus ${ }^{2}$ \\ Accepted: 18 June 2021 / Published online: 10 July 2021 \\ (C) The Author(s), under exclusive licence to Springer Science+Business Media, LLC, part of Springer Nature 2021
}

\begin{abstract}
Purpose of the Review The present review addresses clinicians and gives an overview about the experimental rationale for pharmacological conditioning associated with volatile anesthetics, opioids, and propofol; the current clinical data; and the technical considerations regarding the clinical routine in cardiac anesthesia.

Recent Findings Volatile anesthetics have been standard of care for general anesthesia for cardiac surgery, especially while using cardiopulmonary bypass. The 2019 published MYRIAD trial was not able to show a difference in mortality or cardiac biomarkers for volatile anesthetics compared to total intravenous anesthesia (TIVA), raising the question of equivalence with respect to patient outcome.

Summary Reviewing the literature, the scientific foundation for the belief of clinically relevant conditioning by uninterrupted administration of a volatile anesthetic is weak. TIVA can also be performed safely in patients undergoing cardiac surgery.
\end{abstract}

Keywords Volatile anesthetics $\cdot$ Total intravenous anesthesia $\cdot$ Cardiac surgery $\cdot$ Sevoflurane $\cdot$ Propofol $\cdot$ Desflurane

\section{Introduction}

The question whether the choice of anesthetic is an outcome-determining factor in cardiac surgery has occupied generations of anesthesiologists. During the last two decades, volatile anesthetics have become the anesthetic of choice in cardiac anesthesia. Studies have found preand postconditioning effects of volatile anesthetics, but large clinical trials on patients undergoing coronary artery bypass graft surgery were missing for a long time. The concept of pharmacological conditioning by volatile anesthetics is not only limited to the myocardium,

This article is part of the Topical Collection on Cardiovascular Anesthesia

Christopher Uhlig

christopher.uhlig@herzzentrum-dresden.com

1 Department of Cardiac Anesthesiology, Heart Center Dresden University Hospital, Fetscherstr. 76, 01307 Dresden, Germany

2 Department of Anesthesiology and Intensive Care Medicine, University Hospital and Medical Faculty, Cologne University, Albertus-Magnus-Platz, 50923 Cologne, Germany suggesting beneficial effects over intravenous anesthetics with respect to the reduction of myocardial infarction [1•], acute kidney [2], and lung injury [3]. Such effects have been ascribed to different mechanisms, including inhibition of mitochondrial permeability transition pores as well as activation of complex signaling pathways in the myocardial cells $[1 \bullet, 4,5]$. However, these molecular mechanisms are complex and also influenced by opioids and propofol $[1 \bullet, 6 \bullet]$.

Clinical trials investigating the effects of pharmacological condition with volatile anesthetics compared to total intravenous anesthesia (TIVA) observed a reduction in cardiac biomarkers as well as mortality [7, 8]. The largest and most recently published MYRIAD trial was not able to show a difference in mortality or cardiac biomarkers for volatile anesthetics compared to TIVA [9••], raising the question of equivalence. However, clinicians face different technical and pharmacokinetic challenges during cardiopulmonary bypass either using volatile anesthetics or TIVA [10].

The present review addresses clinicians and gives an overview about the experimental rationale for pharmacological conditioning associated with volatile anesthetics, opioids, and propofol; the current clinical data; and the technical considerations regarding the clinical routine in cardiac anesthesia. 


\section{Experimental Data}

\section{Myocardial Protection}

In experimental studies, the volatile anesthetics sevoflurane [11], desflurane [12], and isoflurane [13] have been shown to reduce the size of myocardial infarction. Such effects have been ascribed to cardioprotective effects by volatile anesthetics, the so-called conditioning. Traditional approaches to cardioprotection focused mainly on optimizing the oxygen supply/demand ratio. The pharmacological "conditioning" by volatile anesthetics is based on an activation of an endogenous "protection program" in the heart which results in longterm protection/resistance against ischemia-reperfusion-injury $[1 \bullet]$. The concept of "conditioning" itself refers to a combination of pre- and postconditioning, which exerts synergistic interactions [1•] (Figure 1). After the first stimulus, a second window of protection occurs hours later, being a result of activated transcriptional factors which alter gene expression $[14,15]$. The molecular mechanisms of conditioning itself are complex and have been summarized in previous reviews $[1 \cdot$, $5,16]$. Briefly, the basic mechanism is the increase of the resistance of the cell against ischemia, or in other words an elongation of the time of tolerance of anaerobic metabolism in the myocardium. Physiologically, the adenosine triphosphate (ATP) production in the cardiomyocyte is realized by anaerobic glycolysis in the cytosol. ATP is transported into the mitochondria to maintain the mitochondrial membrane potential. The protons generated with this reaction lower the intracellular $\mathrm{pH}$ and activate proton/sodium and sodium/calcium channels resulting in an increasing level of cytosolic calcium which is transported into the mitochondria [5]. Together with reactive oxygen species, the calcium activates mitochondrial permeability transition pores (mPTPs), which result in a decoupling of the respiratory chain and swelling of the mitochondria, furthermore triggering apoptotic and necrotic mechanisms $[4,17,18]$. Volatile anesthetics as well as opioids

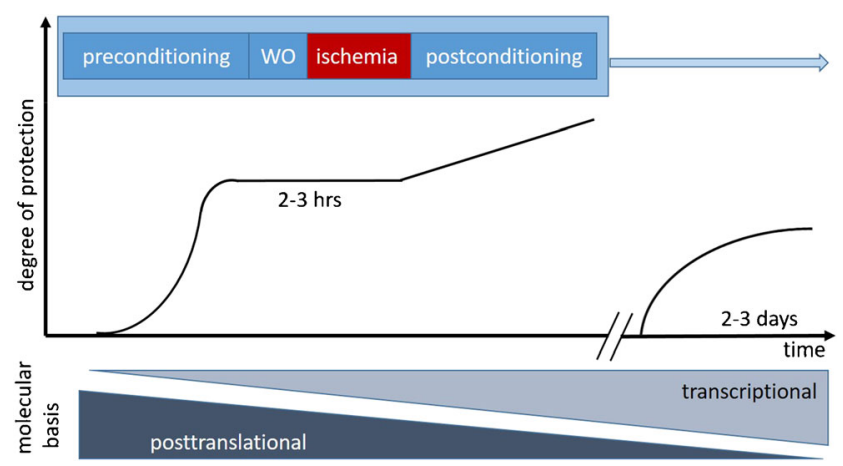

Figure 1 Concept of pharmacological conditioning. Modified from Zaugg et al. [1•]. "Pharmacological conditioning" refers to a combination of pre- and postconditioning. Due to its anti-inflammatory and anti-apoptotic effects, a prolonged protection over days is provided. WO, washout activate via G-protein-coupled receptors, an intracellular signal cascade which results in less mitochondrial calcium and a higher mitochondrial potassium level, less reactive oxygen species (ROS), and a direct inhibition of the mPTPs. In addition, the gene expression in the cardiomyocyte is altered, leading to a transcription of anti-apoptotic genes and opening the "second window" of protection [1•].

Propofol, on the other hand, does not show typical features of conditioning [5]. It does not induce a second window of protection. Presumably, this is caused by inhibition of the protective signaling pathway initiated by volatile anesthetics and opioids through scavenging of reactive oxygen species and therefore activating the MPTP channels [19] and inhibition of $\mathrm{K}_{\mathrm{ATP}}$ channels $[1 \bullet, 5,16]$. However, some trials suggest protective effects of propofol due to its pronounced antioxidant properties mimicking some "pre- or postconditioninglike" effects [20-22]. Yet, the doses used in these trials were very high and out of the clinical routine range [21, 22]. It remains open, whether the scavenging effect of ROS or other mechanisms are causing those "pre- or postconditioning-like" effects $[1 \bullet]$.

As essential partners to hypnotic agents in the clinical routine, opioids are often neglected in the discussion regarding volatile versus TIVA. Experimental data suggests protective and anti-apoptotic effects on the heart [6॰]. Cardiac myocytes are capable of synthesis, storage, and release of opioid receptor peptides $[6 \cdot, 23]$. The therapeutic effects of clinically relevant opioids like morphine, fentanyl, remifentanil, or sufentanil mainly rely on activation of the $\mu$-receptor. However, there are investigations questioning the existence of $\mu$-receptor in the cardiac tissue [6•,24]. Despite that, effects of these opioids are also mediated via $\kappa$ - and $\delta$-receptors, both found on cardiomyocytes [6॰]. In addition, two studies suggested a possible $\mu$-receptor expression in human heart tissue $[25,26]$. However, the opioid-induced cardioprotection is also facilitated through the inhibition of mitochondrial transition pores similar to volatile anesthetics. Furthermore, a complex signal cascade involving sarcolemmal $\mathrm{K}_{\mathrm{ATP}}$ channels, reactive oxygen species, protein kinase $\mathrm{C}$, inducible nitric oxide synthetase and others are induced by opioid receptor activation in the cardiomyocyte contributing to cardioprotection by inhibition of apoptotic pathways [6॰].

In summary, our knowledge on the molecular mechanisms of cardioprotective effects of propofol and opioids is still limited and more studies are warranted.

\section{Other Protective Effects}

The type of anesthesia has also the potential to affect pulmonary and other postoperative complications, since several anesthetic agents may contribute to organ protection aside from the myocardium. With regard to the lungs, volatile anesthetics may protect against lung injury [27] and attenuate 
inflammation [3]. Fukazawa and colleagues summarized a complex signal pathway to prevent acute kidney injury [2].

\section{Clinical Data}

A retrospective register trial by $\mathrm{Oh}$ et al. enrolling 10,440 patients undergoing CAGB surgery showed a lower 3-year all-cause mortality with TIVA compared to volatiles [28]. Yet, the results of this retrospective trial should be interpreted with caution, due to methodical weaknesses caused by the trial design [29]. The first larger clinical randomized controlled trials demonstrating benefits for volatile anesthetics compared to TIVA were published by the group of De Hert and colleagues in 2004 and 2009 analyzing together 934 patients [8, $30,31]$. Table 1 summarizes the six largest randomized controlled trials (RCTs) with respect to patient enrollment in cardiac surgery. In the first of this RCTs, De Hert was able to observe a shorter intensive care unit (ICU) and hospital stay, as well as less inotropic support for a sevoflurane or desflurane versus propofol or midazolam-based TIVA anesthetic regimen [31]. In a second trial, published the same year, the time point of the application of sevoflurane was investigated [30]. When administered throughout the whole on pump coronary artery bypass graft (CABG) surgery, sevoflurane reduced cardiac biomarkers, as well as length of ICU and hospital stay compared to the isolated application as pre- or postconditioning and propofol-based TIVA [30]. A reduction in 1-year mortality as well as length of hospital stay was observed for sevoflurane and desflurane versus TIVA without affecting postoperative cardiac biomarkers [8]. Another trial by Likhvantsev et al. showed lower postoperative cardiac biomarkers and shorter hospital stay for sevoflurane versus propofol-based TIVA, but was unable to observe an effect on in-hospital or 1-year mortality [7]. All these previous mentioned clinical trials were not powered for mortality.

A Bayesian network meta-analysis including primarily trials on CABG surgery demonstrated a reduction of in-hospital mortality for volatile anesthetics favoring especially sevoflurane and desflurane [33]. Those results are mostly based on the trials published by De Hert and colleagues [8, $30,31]$ ranging approximately $40 \%$ of the weight of the effect size. In another meta-analysis published by our group, analyzing the data of 3205 cardiac surgical patients volatile anesthetics were associated with a reduction of overall mortality and non-pulmonary complications (mainly cardiac events) after cardiac surgery [34]. An effect on postoperative pulmonary complications could not be found in this meta-analysis [34]. However, the risk for bias was medium to high in most trials included in the analyses and none of these trials was powered for mortality as primary outcome. Therefore, the results need to be interpreted with caution.
Table 1 Trial overview. Depicted are the six largest trials with respect to patient enrollment. $A K I$, acute kidney injury; $C A B G$, coronary artery bypass graft; Des, desflurane; Fent, fentanyl; $I C U$, intensive care unit; $L O S$, length of stay; Mida, midazolam; PPCs, postoperative pulmonary complications; Prop, propofol; Remi, remifentanil; Sevo, sevoflurane; Suf, sufentanil; TIVA, total intravenous anesthesia; +, superior to control/TIVA group; $n . s$. , not specified; $n$.a., not statistically analyzed

\begin{tabular}{|c|c|c|c|c|c|c|c|c|c|c|c|c|}
\hline \multirow[t]{2}{*}{ Trial } & \multirow{2}{*}{$\begin{array}{l}\text { Type } \\
\text { of } \\
\text { surgery }\end{array}$} & \multirow{2}{*}{$\begin{array}{l}\text { Type of } \\
\text { volatile } \\
\text { (number of } \\
\text { patients) }\end{array}$} & \multirow{2}{*}{$\begin{array}{l}\text { Type of } \\
\text { TIVA } \\
\text { (number of } \\
\text { patients) }\end{array}$} & \multirow{2}{*}{$\begin{array}{l}\text { Type of } \\
\text { opioid } \\
\text { Volatile } \\
\text { (number of } \\
\text { patients) }\end{array}$} & \multirow{2}{*}{$\begin{array}{l}\text { Type of } \\
\text { opioid TIVA } \\
\text { (number of } \\
\text { patients) }\end{array}$} & \multicolumn{7}{|l|}{ Outcome } \\
\hline & & & & & & Mortality & $\begin{array}{l}\text { Cardiac } \\
\text { events }\end{array}$ & $\begin{array}{l}\text { Cardiac } \\
\text { biomarkers }\end{array}$ & PPCs & AKI & $\begin{array}{l}\text { LOS } \\
\text { ICU }\end{array}$ & $\begin{array}{l}\text { LOS } \\
\text { hospital }\end{array}$ \\
\hline De Hert I [31] & CABG & $\begin{array}{l}\text { Sevo }(80) \\
\text { Des }(80)\end{array}$ & $\begin{array}{l}\text { Prop (80) } \\
\text { Mida (80) }\end{array}$ & $\begin{array}{l}\text { Remi } \\
\text { (All groups) }\end{array}$ & Remi & $\begin{array}{l}= \\
\text { (In-hospital) }\end{array}$ & $=$ & $\begin{array}{l}\text { Sevo+ } \\
\text { Des+ }\end{array}$ & $=$ & n.s. & $\begin{array}{c}\text { Sevo } \\
+ \\
\text { Des+ }\end{array}$ & $\begin{array}{l}\text { Sevo+ } \\
\text { Des+ }\end{array}$ \\
\hline $\begin{array}{l}\text { De Hert II } \\
{[30]}\end{array}$ & $\mathrm{CABG}$ & Sevo (150) & Prop (50) & Remi & Remi & $=$ & $=$ & Sevo+ & & n.s. & Sevo+ & Sevo+ \\
\hline $\begin{array}{l}\text { Lorsomradee } \\
\text { [32] }\end{array}$ & $\mathrm{CABG}$ & Sevo (160) & Prop (160) & Fent & Fent & $=$ & $=$ & $=$ & n.s. & $=$ & $=$ & $=$ \\
\hline De Hert [8] & CABG & $\begin{array}{l}\text { Sevo (132) } \\
\text { Des (137) }\end{array}$ & n.s. (145) & $\begin{array}{l}\text { n.s. (all } \\
\text { groups) }\end{array}$ & n.s. & $\begin{array}{l}\text { Sevo+ } \\
\text { Des+ } \\
\text { (1 year) }\end{array}$ & $=$ & $=$ & n.s. & n.s. & n.s. & n.a. \\
\hline $\begin{array}{l}\text { Likhvantsev } \\
\text { [7] }\end{array}$ & CABG & Sevo (437) & Prop (431) & $\begin{array}{l}\text { Fent } \\
\text { (Both groups) }\end{array}$ & Fent & $\begin{array}{l}\text { Sevo }+ \\
(1 \text { year })\end{array}$ & n.s. & Sevo + & n.s. & n.s. & n.s. & Sevo + \\
\hline Landoni $[9 \bullet \bullet]$ & CABG & $\begin{array}{l}\text { n.s. } \\
\text { Sevo } \\
\quad(2255) \\
\text { Des (248) } \\
\text { Iso (157) } \\
\text { Total 2709 }\end{array}$ & $\begin{array}{l}\text { n.s. } \\
\text { Prop } \\
\quad(2297) \\
\text { Mida } \\
(419) \\
\text { Other } \\
\quad(335) \\
\text { Total 2691 }\end{array}$ & $\begin{array}{l}\text { n.s. } \\
\text { Fent (2238) } \\
\text { Suf (389) } \\
\text { Remi (185) }\end{array}$ & $\begin{array}{l}\text { n.s. } \\
\text { Fent (2198) } \\
\text { Suf (385) } \\
\text { Remi (258) }\end{array}$ & $\begin{array}{l}=(1 \text { year }) \\
=(30 \text { days })\end{array}$ & $=$ & n.s. & n.s. & $=$ & $=$ & $=$ \\
\hline
\end{tabular}


The largest and most recent trial in this field is the so-called MYRIAD trial, published by Landoni and colleagues [9••]. This multicenter RCT enrolling 5400 patients undergoing elective CABG surgery was unable to determine a statistically significant difference between volatile anesthetics and TIVA in relation to 1-year mortality, length of hospital stay, or myocardial infarction and, consequently, was stopped for futility. Since its publication, the MYRIAD trial has been discussed extensively among clinicians. First, the trial was not planned for 5400, but 10,600 patients, raising concerns about underpowering. However, considering the small difference between groups for the primary outcome "1-year mortality" of 0.2 percentage points $(2.8 \%$ versus $3.0 \%$; 75 versus 79 [number of patients]; volatile versus TIVA, respectively), a total of 372,984 patients (186,492 patients per group) would be necessary to detect a difference in 1-year mortality with $90 \%$ statistical power and alpha of 0.05 , according to the authors [35]. Second, the type and dosage of the volatile and TIVA agents were at the choice of the treating clinician which may have led to "underdosing" of volatile anesthetics, especially in case of high volume use of opioids. On the other side, this pragmatic approach made this trial feasible in almost every hospital performing CABG surgery representing "reallife" conditions. Third, only 482 patients in the volatile group received volatile anesthetics during cardiopulmonary bypass. As discussed before, the timing of the administration of the volatile anesthetic is crucial, since these agents exhibit the highest protective effect when administered during cardiopulmonary bypass (CPB) [1・, 30].

A recent meta-analysis including the MYRIAD trial, accounting for $57 \%$ of included patients, showed no difference in mortality, cardiac biomarkers, and time to extubation between TIVA and volatile anesthetics [36••]. While most of the data on the administration of volatile anesthetics is published for elective CABG surgery, clinical data in patients undergoing heart valve surgery is rare. A recent meta-analysis summarizing the data for volatile anesthetics in heart valve surgery found no difference between TIVA and volatile anesthetics with respect to mortality, postoperative complications, length of ventilator support, ICU, and hospital stay [37•].

In case of one lung ventilation, De Conno and colleagues found a reduction of proinflammatory cytokines for volatile anesthetics compared to propofol-based TIVA [38]. Schilling et al. observed a reduction of alveolar cytokines and systemic inflammatory response for sevoflurane and desflurane compared to propofol [39]. Another trial by Beck-Schimmer was unable to find a difference between desflurane and propofolbased TIVA on patient outcome after lung surgery [40]. Although all of those patients had thoracic surgery, one lung ventilation is also used during lateral thoracotomy for minimally invasive cardiac surgery.

In summary, the MYRIAD study has included markedly more patients than all other studies in this field together.
Therefore, the data contributed by the MYRIAD trial dominate all meta-analyses on this topic and the conclusion based on MYRIAD data has to be considered the current state of knowledge. However, De Hert et al. have found a clinically relevant conditioning effect by volatile anesthetics only in the group with continuous/uninterrupted administration of the volatile anesthetic before, during, and after cardiopulmonary bypass, i.e., throughout anesthesia and surgery [30]. In the MYRIAD trial, the majority of patients did not receive a volatile anesthetic during CPB [9••]. Therefore, the MYRIAD trial $[9 \cdot \bullet]$ does not provide data to investigate whether or not the results by De Hert et al. [30] are of clinical relevance or just a finding by chance in a study with a small sample size.

\section{Technical and Pharmacokinetic Considerations}

\section{Volatile Anesthetics}

Although volatile anesthetics are widely used during CPB, not all manufacturers equip their CPB circuits for the attachment of vaporizers for volatile anesthetics [10, 41]. Several considerations need to be taken into account by the anesthetists and perfusionist while using volatile anesthetics during CPB: (1) a variable uptake of volatile anesthetics depending on the oxygenator type, (2) the difficulty to maintain a steady-state plasma concentration of volatile anesthetics during different phases of CPB and variable fresh gas flow rates, (3) avoiding awareness, (4) unexpected damage to parts of the CPB [42, 43], and (5) air pollution of operating room due to inefficient scavenging of waste gas [44, 45].

The oxygenator type mainly determines the rate of transfer of volatile anesthetics. Two types of hollow fiber membrane oxygenators are currently available: the microporous polypropylene (PPL) and the plasma-tight polymethylpentene (PMP) [46]. PPL membranes are recommended by the European Association of Cardio-Thoracic Surgery/European Association of Cardiothoracic Anaesthesiology/European Board of Cardiovascular Perfusion (EACTS/EACTA/EBCP) guidelines as first choice, because this membrane type allows the best transfer of volatile anesthetics [47]. Plasma-tight PMP membrane oxygenators are less efficient for diffusion of fresh gas and volatile anesthetic agents and, therefore, have an increased risk of intraoperative awareness [48, 49]. The EACTS/EACTA/EBCP guidelines do not recommend the use of plasma-tight PMP membrane oxygenators when volatile agents are administered during CPB [47]. In case of planned TIVA during CPB, plasma-tight PMP membrane oxygenators are feasible allowing a smooth transition from balanced anesthesia with volatiles to TIVA [46, 50]. The oxygenator fresh gas flow is the carrier gas for the delivery of volatile anesthetics. An increase of the fresh gas flow rate 
enhances the uptake and solubility of volatile anesthetics in the plasma [51]. Higher rates of fresh gas flow may be necessary during CPG for instance to achieve normocapnia when carbon dioxide is inflated in the pericardial space to decrease the risk of air embolism. This may result in a higher volatile plasma concentration independent of blood/gas solubility assuming the concentration of the volatile agent is maintained constant [51].

On the other hand, hemodilution through the priming solutions of the extracorporal circuit reduces the blood solubility of volatile anesthetics resulting in lower plasma concentrations $[49,52]$. In case of hypothermia during CPB, the uptake and plasma solubility of volatile anesthetics increase when temperature decreases. At the commencement of CPB, this effect might be balanced by the opposing effect induced by the prime hemodilution [10]. Furthermore, during rewarming and weaning from $\mathrm{CPB}$, the change in temperature is usually faster than the increase in hematocrit. This effect decreases the blood/gas solubility to the lowest level of the entire cardiac surgery, facilitating washout of volatile anesthetics and resulting in a rapid decrease in depth of anesthesia [53]. All these special pharmacokinetic characteristics are accompanied by challenges in monitoring of the delivery of volatile anesthetics. The redundant venting systems deployed at the end of the exhaust port of the membrane oxygenator to eliminate the risk of overpressurization in the oxygenator makes it difficult to measure the concentrations of volatile anesthetic agent in the exhaust port precisely $[10,52]$ (Figure 2). The EACTS/ EACTA/EBCP guidelines recommend the measurement of all incoming and outgoing gases should be installed and maintained [47]. In addition, the volatile anesthetic concentration at the oxygenator exhaust should be maintained at least at the same level as before CPB and greater during rewarming [47]. However, especially the measurement of volatile anesthetics at the exhaust port is technical complex and dependent on the type of oxygenator. Processed electroencephalography, such as the bispectral index (BIS), is essential to reduce the incidence of awareness during CPB [54]. However, there are some trials showing a poor correlation between the measured volatile gas concentration at the exhaust port of the oxygenator and BIS [51, 55].

Another important factor is the occupational hazard and air pollution of the operating room. To avoid this, a scavenging system at the outlet of the oxygenator is recommended [47, $56,57]$. Otherwise, the anesthesiologist, surgical staff, and the perfusionist will be exposed to waste volatile gas [56]. However, the occupational exposure standards are not uniform, but vary from country to country. In addition, there is no proprietary scavenging equipment specifically designed for the oxygenators available [10]. Nevertheless, adaptions to the anesthetic gas scavenging system are feasible $[45,58$, 59], but often lack official certification. Also, the contribution to the greenhouse effect by depletion of the ozone layer, especially with isoflurane, should be considered [60].

Accidental spillage of liquid volatile agents over the polycarbonate shell reservoir or other CPB lines can cause severe damage and needs to be avoided [10]. The use of keyed vaporizers is recommended.

\section{Total Intravenous Anesthesia}

For anesthesia maintenance during CABG surgery with TIVA, the two most frequent drugs used are propofol $(85.3 \%)$ and midazolam $(15.6 \%)$ [9••]. Propofol has the advantage of improved controllability. The administration of midazolam is associated with increased risk for postoperative delirium $[61,62]$. Due to its frequent use, only propofol will be discussed in this narrative review. The extracorporal circuit

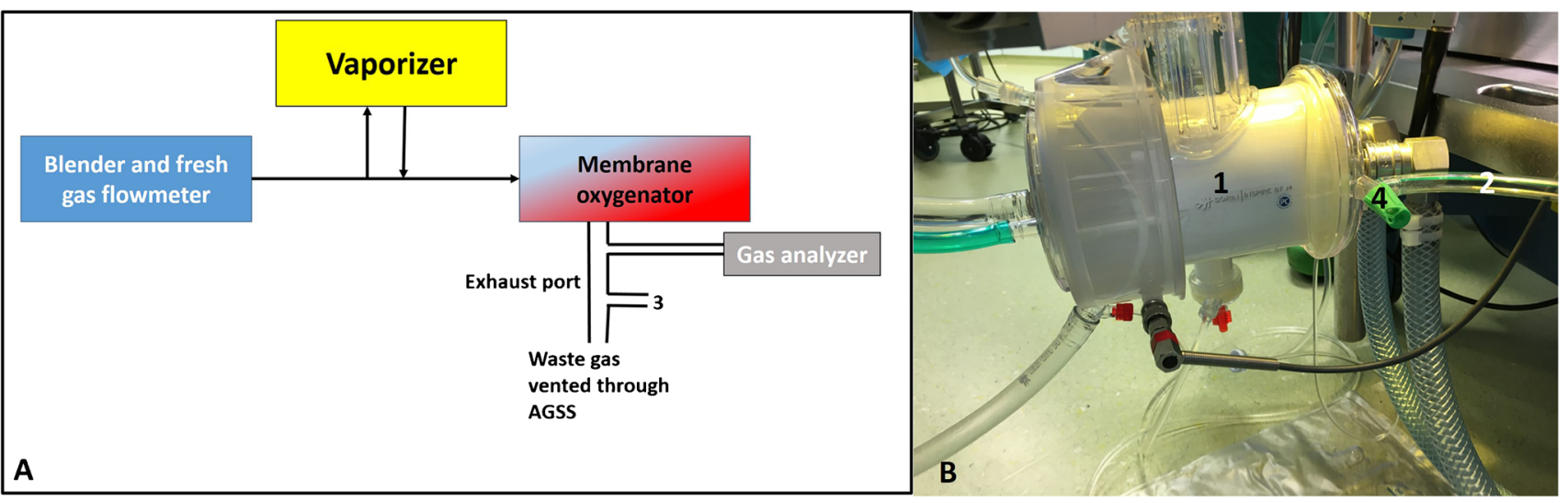

Figure 2 Anesthesia gas scavenging system. Modified from Yeoh and colleagues [10]. This figure shows a diagram of anesthesia gas scavenging system (A) and in real life $(\mathbf{B})$. The vaporizer is installed between the blender and fresh gas flowmeter and the oxygenator. The gas analyzer samples waste gas from the exhaust port. The incorporation of another gas inlet 1 for entrainment of atmospheric air regulates the negative pressure within the exhaust port which is generated by the anesthesia gas scavenging system (AGSS). This active scavenging will lead to underestimation of the volatile anesthetic gas concentration in the waste gas sampled by the gas analyzer. 1: membrane oxygenator, 2 : anesthesia gas scavenging system, 4: exhaust port 
requires no special adaption to the use of propofol as continuous infusion [10]. The depth of anesthesia should be also monitored with processed electroencephalogram like BIS [63]. The free fraction of propofol in the plasma is influenced by the plasma protein binding capacity, hemodilution, the degree of adsorption to the extracorporeal circuit/membrane, the effect of hypothermia to the hepatic clearance of propofol, and other pharmacokinetic variation throughout different age groups [10].

With initiation of the CPB, the plasma concentration of the propofol decreases as well as the concentration of albumin, $\alpha 1$-glycoproteine, and red blood cells, which all bind propofol, resulting in a lower and variable free fraction of propofol $[64,65]$. Even when assuming a homogeneous dilution of free propofol, protein bind propofol, and the binding proteins, the increased free fraction of propofol will offset the reduction in free drug concentration to some extent $[10,47$, 65]. Because of its lipid solubility propofol will be sequestrated in the extracorporal circuit very quickly contributing to lower propofol plasma concentration [64]. Uncoated and heparin- or phosphorylcholine-coated circuits bind lipophilic drugs excellently [66, 67]. These mechanisms need to be considered and counteracted by increase of propofol concentration while avoiding awareness during CPB.

Hypothermia reduces the hepatic blood flow approximately $20 \%$ resulting in a lower propofol extraction [68]. For instance, at core temperature of $34{ }^{\circ} \mathrm{C}$, the propofol plasma concentration is $28 \%$ higher than at $37^{\circ} \mathrm{C}[69]$.

\section{Implications for Future Studies}

It is worth noting that the choice of anesthetic is not the only outcome relevant factor in cardiac surgery, which could be influenced by the anesthesiologist. Thermal care, hemoglobin and coagulation management, glycemic control, a protective ventilation strategy, and heart rate control also affect the outcome of the patient $[1 \bullet]$. During the last years, progress in cardiac surgical techniques, anesthetic management, and postoperative care has reduced perioperative mortality. There are several reasons why the "clear" signal of pharmacological conditioning by volatile anesthetics found in several experimental studies could be less and less better translated into a clear improvement of outcome in clinical trials over time: First, the outcome parameter mortality is very robust, but also a definitive endpoint, whereas length of hospital or ICU stay may be dependent on the health care system in each country. Second, the inclusion and exclusion criteria of clinical trials often choose a "healthier" study population compared to the "real-life" cohort. Third, confounding by indication bias especially in coronary bypass surgery may have influenced the patient population undergoing CABG surgery. While in the last decade also complex percutaneous coronary interventions have become clinical routine [70], patients selected for CABG may have higher morbidity. Fourth, the protective role of opioid-induced pharmacological conditioning could have been underestimated in the previous clinical studies. Clinical trials investigating the effects of different opioids on mortality, cardiac, and non-cardiac complications are warranted.

\section{Conclusion}

The choice of anesthetic has been considered an outcomerelevant parameter in cardiac surgery favoring pharmacological conditioning with uninterrupted administration of volatile anesthetics throughout the entire cardiac surgery. These findings are based on a trial by the Group of De Hert with small sample size. No other published study has tested and confirmed their findings. Therefore, the scientific foundation for the belief of clinically relevant conditioning by uninterrupted administration of a volatile anesthetic is weak. The selection of anesthetic should be a team decision of the anesthesiologist, the perfusionist, and the cardiac surgeon considering the technical and pharmacokinetic challenges focused on each patients' demands. Further large randomized controlled trials are warranted investigating the role of volatile anesthetics, opioids, and propofol on patient outcome in cardiac surgery.

\section{Compliance with Ethical Standards}

Conflict of Interest The authors do not have any potential conflicts of interest to disclose.

Human and Animal Rights and Informed Consent This article does not contain any studies with human or animal subjects performed by any of the authors.

\section{References}

Papers of particular interest, published recently, have been highlighted as:

- Of importance

• Of major importance

1. Zaugg M, Lucchinetti E, Behmanesh S, Clanachan AS. Anesthetic cardioprotection in clinical practice from proof-of-concept to clinical applications. Curr Pharm Des. 2014;20(36):5706-26. https:// doi.org/10.2174/1381612820666140204120829. This review highlights the experiemntal rationale of pharmacological conditioning.

2. Fukazawa K, Lee HT. Volatile anesthetics and AKI: risks, mechanisms, and a potential therapeutic window. J Am Soc Nephrol. 2014;25(5):884-92. https://doi.org/10.1681/ASN.2013111215.

3. Fortis S, Spieth PM, Lu WY, Parotto M, Haitsma JJ, Slutsky AS, et al. Effects of anesthetic regimes on inflammatory responses in a 
rat model of acute lung injury. Intensive Care Med. 2012;38(9): 1548-55. https://doi.org/10.1007/s00134-012-2610-4.

4. Agarwal B, Stowe DF, Dash RK, Bosnjak ZJ, Camara AK. Mitochondrial targets for volatile anesthetics against cardiac ischemia-reperfusion injury. Front Physiol. 2014;5:341. https:// doi.org/10.3389/fphys.2014.00341.

5. Zaugg M, Lucchinetti E, Uecker M, Pasch T, Schaub MC. Anaesthetics and cardiac preconditioning. Part I. Signalling and cytoprotective mechanisms. Br J Anaesth. 2003;91(4):551-65. https://doi.org/10.1093/bja/aeg205.

6. Tanaka K, Kersten JR, Riess ML. Opioid-induced cardioprotection. Curr Pharm Des. 2014;20(36):5696-705. https://doi.org/10.2174/ 1381612820666140204120311 . This is a very good review regarding opioid induced cardiac protection.

7. Likhvantsev VV, Landoni G, Levikov DI, Grebenchikov OA, Skripkin YV, Cherpakov RA. Sevoflurane versus total intravenous anesthesia for isolated coronary artery bypass surgery with cardiopulmonary bypass: a randomized trial. J Cardiothorac Vasc Anesth. 2016;30(5):1221-7. https://doi.org/10.1053/j.jvca.2016.02.030.

8. De Hert S, Vlasselaers D, Barbe R, Ory JP, Dekegel D, Donnadonni R, et al. A comparison of volatile and non volatile agents for cardioprotection during on-pump coronary surgery. Anaesthesia. 2009;64(9):953-60. https://doi.org/10.1111/j.13652044.2009.06008.x.

9.• Landoni G, Lomivorotov VV, Nigro Neto C, Monaco F, Pasyuga $\mathrm{VV}$, Bradic N, et al. Volatile anesthetics versus total intravenous anesthesia for cardiac surgery. N Engl J Med. 2019;380(13):1214 25. https://doi.org/10.1056/NEJMoa1816476. This narrative review summarizes technical and pharmacokinetic challenges while using volatile anesthestics or TIVA.

10. Yeoh CJ, Hwang NC. Volatile anesthesia versus total intravenous anesthesia during cardiopulmonary bypass: a narrative review on the technical challenges and considerations. J Cardiothorac Vasc Anesth. 2020;34(8):2181-8. https://doi.org/10.1053/j.jvca.2020. 03.013 .

11. Fradorf J, Huhn R, Weber NC, Ebel D, Wingert N, Preckel B, et al. Sevoflurane-induced preconditioning: impact of protocol and aprotinin administration on infarct size and endothelial nitricoxide synthase phosphorylation in the rat heart in vivo. Anesthesiology. 2010;113(6):1289-98. https://doi.org/10.1097/ ALN.0b013e3181f97fec.

12. Piriou V, Chiari P, Lhuillier F, Bastien O, Loufoua J, Raisky O, et al. Pharmacological preconditioning: comparison of desflurane, sevoflurane, isoflurane and halothane in rabbit myocardium. $\mathrm{Br} \mathrm{J}$ Anaesth. 2002;89(3):486-91.

13. Kersten JR, Schmeling TJ, Pagel PS, Gross GJ, Warltier DC. Isoflurane mimics ischemic preconditioning via activation of K(ATP) channels: reduction of myocardial infarct size with an acute memory phase. Anesthesiology. 1997;87(2):361-70. https:// doi.org/10.1097/00000542-199708000-00024.

14. Bravo C, Kudej RK, Yuan C, Yoon S, Ge H, Park JY, et al. Metabolomic analysis of two different models of delayed preconditioning. J Mol Cell Cardiol. 2013;55:19-26. https://doi.org/10. 1016/j.yjmec.2012.10.012.

15. Marber MS, Latchman DS, Walker JM, Yellon DM. Cardiac stress protein elevation 24 hours after brief ischemia or heat stress is associated with resistance to myocardial infarction. Circulation. 1993;88(3):1264-72. https://doi.org/10.1161/01.cir.88.3.1264.

16. Zaugg M, Schaub MC. Signaling and cellular mechanisms in cardiac protection by ischemic and pharmacological preconditioning. $\mathrm{J}$ Muscle Res Cell Motil. 2003;24(2-3):219-49. https://doi.org/10. 1023/a:1026021430091.

17. Di Lisa F, Canton M, Carpi A, Kaludercic N, Menabo R, Menazza $\mathrm{S}$, et al. Mitochondrial injury and protection in ischemic pre- and postconditioning. Antioxid Redox Signal. 2011;14(5):881-91. https://doi.org/10.1089/ars.2010.3375.
18. Murphy E, Steenbergen C. Mechanisms underlying acute protection from cardiac ischemia-reperfusion injury. Physiol Rev. 2008;88(2):581-609. https://doi.org/10.1152/physrev.00024.2007.

19. Zaugg M, Wang L, Zhang L, Lou PH, Lucchinetti E, Clanachan AS. Choice of anesthetic combination determines $\mathrm{Ca} 2+$ leak after ischemia-reperfusion injury in the working rat heart: favorable versus adverse combinations. Anesthesiology. 2012;116(3):648-57. https://doi.org/10.1097/ALN.0b013e318247225a.

20. Assad AR, Delou JM, Fonseca LM, Villela NR, Nascimento JH, Vercosa N, et al. The role of KATP channels on propofol preconditioning in a cellular model of renal ischemia-reperfusion. Anesth Analg. 2009;109(5):1486-92. https://doi.org/10.1213/ANE. 0b013e3181b76396.

21. Xia Z, Godin DV, Ansley DM. Propofol enhances ischemic tolerance of middle-aged rat hearts: effects on $15-\mathrm{F}(2 \mathrm{t})$-isoprostane formation and tissue antioxidant capacity. Cardiovasc Res. 2003;59(1):113-21. https://doi.org/10.1016/s0008-6363(03) 00351-1.

22. Javadov SA, Lim KH, Kerr PM, Suleiman MS, Angelini GD, Halestrap AP. Protection of hearts from reperfusion injury by propofol is associated with inhibition of the mitochondrial permeability transition. Cardiovasc Res. 2000;45(2):360-9. https://doi. org/10.1016/s0008-6363(99)00365-x.

23. Barron BA, Jones CE, Caffrey JL. Pericardial repair depresses canine cardiac catecholamines and met-enkephalin. Regul Pept. 1995;59(3):313-20. https://doi.org/10.1016/0167-0115(95)00086q.

24. Peng J, Sarkar S, Chang SL. Opioid receptor expression in human brain and peripheral tissues using absolute quantitative real-time RT-PCR. Drug Alcohol Depend. 2012;124(3):223-8. https://doi. org/10.1016/j.drugalcdep.2012.01.013.

25. Bell SP, Sack MN, Patel A, Opie LH, Yellon DM. Delta opioid receptor stimulation mimics ischemic preconditioning in human heart muscle. J Am Coll Cardiol. 2000;36(7):2296-302. https:// doi.org/10.1016/s0735-1097(00)01011-1.

26. Head BP, Patel HH, Roth DM, Lai NC, Niesman IR, Farquhar MG, et al. G-protein-coupled receptor signaling components localize in both sarcolemmal and intracellular caveolin-3-associated microdomains in adult cardiac myocytes. J Biol Chem. 2005;280(35): 31036-44. https://doi.org/10.1074/jbc.M502540200.

27. Faller S, Strosing KM, Ryter SW, Buerkle H, Loop T, Schmidt R, et al. The volatile anesthetic isoflurane prevents ventilator-induced lung injury via phosphoinositide 3-kinase/Akt signaling in mice. Anesth Analg. 2012;114(4):747-56. https://doi.org/10.1213/ANE. 0b013e31824762fo.

28. Oh TK, Song IA. Total intravenous anesthesia was associated with better survival outcomes after coronary artery bypass grafting: a retrospective cohort study with 3-year follow-up in South Korea. J Cardiothorac Vasc Anesth. 2020;34(12):3250-6. https://doi.org/ 10.1053/j.jvca.2020.07.025.

29. Sellers D, Fedorko L, Djaiani G. Myocardial preconditioning with volatile anesthetics: goodbye to all that? J Cardiothorac Vasc Anesth. 2020;34(12):3257-8. https://doi.org/10.1053/j.jvca.2020. 08.032 .

30. De Hert SG, Van der Linden PJ, Cromheecke S, Meeus R, Nelis A, Van Reeth V, et al. Cardioprotective properties of sevoflurane in patients undergoing coronary surgery with cardiopulmonary bypass are related to the modalities of its administration. Anesthesiology. 2004;101(2):299-310. https://doi.org/10.1097/00000542200408000-00009.

31. De Hert SG, Van der Linden PJ, Cromheecke S, Meeus R, ten Broecke PW, De Blier IG, et al. Choice of primary anesthetic regimen can influence intensive care unit length of stay after coronary surgery with cardiopulmonary bypass. Anesthesiology. 2004;101(1):9-20. https://doi.org/10.1097/00000542-20040700000005 . 
32. Lorsomradee S, Cromheecke S, Lorsomradee S, De Hert SG. Effects of sevoflurane on biomechanical markers of hepatic and renal dysfunction after coronary artery surgery. J Cardiothorac Vasc Anesth. 2006;20(5):684-90. https://doi.org/10.1053/j.jvca. 2006.02.035.

33. Landoni G, Greco T, Biondi-Zoccai G, Nigro Neto C, Febres D, Pintaudi M, et al. Anaesthetic drugs and survival: a Bayesian network meta-analysis of randomized trials in cardiac surgery. Br J Anaesth. 2013;111(6):886-96. https://doi.org/10.1093/bja/aet231.

34. Uhlig C, Bluth T, Schwarz K, Deckert S, Heinrich L, De Hert S, et al. Effects of volatile anesthetics on mortality and postoperative pulmonary and other complications in patients undergoing surgery: a systematic review and meta-analysis. Anesthesiology. 2016;124(6):1230-45. https://doi.org/10.1097/ALN. 0000000000001120 .

35. Landoni G, Nigro Neto C, Lomivorotov VV. Anesthesia for cardiac surgery. Reply N Engl J Med. 2019;381(1):97-8. https://doi.org/10. 1056/NEJMc1905784.

36.• Beverstock J, Park T, Alston RP, Song CCA, Claxton A, Sharkey $\mathrm{T}$, et al. A comparison of volatile anesthesia and total intravenous anesthesia (TIVA) effects on outcome from cardiac surgery: a systematic review and meta-analysis. J Cardiothorac Vasc Anesth. 2021;35(4):1096-105. https://doi.org/10.1053/j.jvca.2020.10.036. This is the most recent meta-analysis on the topic volatile anesthetics vs. TIVA in cardiac surgery.

37. Ren SF, Yu H, Guo YQ, Yu H. Inhalation versus intravenous anesthesia for adults undergoing heart valve surgery: a systematic review and meta-analysis. Minerva Anestesiol. 2019;85(6):66575. https://doi.org/10.23736/S0375-9393.19.13377-9. This is the most recent meta-analysis regarding volatile anesthetics vs. TIVA in cardiac valve surgery.

38. De Conno E, Steurer MP, Wittlinger M, Zalunardo MP, Weder W, Schneiter D, et al. Anesthetic-induced improvement of the inflammatory response to one-lung ventilation. Anesthesiology. 2009;110(6):1316-26. https://doi.org/10.1097/ALN. 0b013e3181a10731.

39. Schilling T, Kozian A, Senturk M, Huth C, Reinhold A, Hedenstierna $\mathrm{G}$, et al. Effects of volatile and intravenous anesthesia on the alveolar and systemic inflammatory response in thoracic surgical patients. Anesthesiology. 2011;115(1):65-74. https://doi. org/10.1097/ALN.0b013e318214b9de.

40. Beck-Schimmer B, Bonvini JM, Braun J, Seeberger M, Neff TA, Risch TJ, et al. Which anesthesia regimen is best to reduce morbidity and mortality in lung surgery?: a multicenter randomized controlled trial. Anesthesiology. 2016;125(2):313-21. https://doi.org/ 10.1097/ALN.0000000000001164.

41. Nigro Neto C, Landoni G, Cassara L, De Simone F, Zangrillo A, Tardelli MA. Use of volatile anesthetics during cardiopulmonary bypass: a systematic review of adverse events. J Cardiothorac Vasc Anesth. 2014;28(1):84-9. https://doi.org/10.1053/j.jvca.2013.05. 030 .

42. Walls JT, Curtis JJ, McClatchey BJ, Wood D. Adverse effects of anesthetic agents on polycarbonate plastic oxygenators. J Thorac Cardiovasc Surg. 1988;96(4):667-8.

43. Cooper S, Levin R. Near catastrophic oxygenator failure. Anesthesiology. 1987;66(1):101-2. https://doi.org/10.1097/ 00000542-198701000-00037.

44. Blokker-Veldhuis MJ, Rutten PM, De Hert SG. Occupational exposure to sevoflurane during cardiopulmonary bypass. Perfusion. 2011;26(5):383-9. https://doi.org/10.1177/0267659111409971.

45. Hoerauf K, Harth M, Wild K, Hobbhahn J. Occupational exposure to desflurane and isoflurane during cardiopulmonary bypass: is the gas outlet of the membrane oxygenator an operating theatre pollution hazard? Br J Anaesth. 1997;78(4):378-80. https://doi.org/10. 1093/bja/78.4.378.
46. Barry AE, Chaney MA, London MJ. Anesthetic management during cardiopulmonary bypass: a systematic review. Anesth Analg. 2015;120(4):749-69. https://doi.org/10.1213/ANE. 0000000000000612.

47. Task Force M, Kunst G, Milojevic M, Boer C, De Somer F, Gudbjartsson T, et al. 2019 EACTS/EACTA/EBCP guidelines on cardiopulmonary bypass in adult cardiac surgery. Br J Anaesth. 2019;123(6):713-57. https://doi.org/10.1016/j.bja.2019.09.012.

48. Philipp A, Wiesenack C, Behr R, Schmid FX, Birnbaum DE. High risk of intraoperative awareness during cardiopulmonary bypass with isoflurane administration via diffusion membrane oxygenators. Perfusion. 2002;17(3):175-8. https://doi.org/10.1191/ 0267659102pf566oa.

49. Wiesenack C, Wiesner G, Keyl C, Gruber M, Philipp A, Ritzka M, et al. In vivo uptake and elimination of isoflurane by different membrane oxygenators during cardiopulmonary bypass. Anesthesiology. 2002;97(1):133-8. https://doi.org/10.1097/ 00000542-200207000-00019.

50. Prasser C, Zelenka M, Gruber M, Philipp A, Keyser A, Wiesenack C. Elimination of sevoflurane is reduced in plasma-tight compared to conventional membrane oxygenators. Eur J Anaesthesiol. 2008;25(2):152-7. https://doi.org/10.1017/S0265021507001330.

51. Nitzschke R, Wilgusch J, Kersten JF, Trepte CJ, Haas SA, Reuter DA, et al. Changes in sevoflurane plasma concentration with delivery through the oxygenator during on-pump cardiac surgery. Br J Anaesth. 2013;110(6):957-65. https://doi.org/10.1093/bja/aet018.

52. Nigro Neto C, De Simone F, Cassara L, Dos Santos Silva CG, Maranhao Cardoso TA, Carco F, et al. Tricks, tips, and literature review on the adapted vaporize system to deliver volatile agents during cardiopulmonary bypass. Ann Card Anaesth. 2016;19(2): 240-4. https://doi.org/10.4103/0971-9784.179592.

53. Zhou JX, Liu J. Dynamic changes in blood solubility of desflurane, isoflurane, and halothane during cardiac surgery. J Cardiothorac Vasc Anesth. 2001;15(5):555-9. https://doi.org/10.1053/jcan. 2001.26529.

54. Kunisawa T, Ueno M, Suzuki A, Takahata O, Iwasaki H. Bispectral index monitor prevented intraoperative awareness during partial cardiopulmonary bypass. J Cardiothorac Vasc Anesth. 2010;24(4):740. https://doi.org/10.1053/j.jvca.2009.07.011.

55. Chandran Mahaldar DA, Gadhinglajkar S, Sreedhar R. Sevoflurane requirement to maintain bispectral index-guided steady-state level of anesthesia during the rewarming phase of cardiopulmonary bypass with moderate hypothermia. J Cardiothorac Vasc Anesth. 2013;27(1):59-62. https://doi.org/10.1053/j.jvca.2012.05.017.

56. Mierdl S, Byhahn C, Abdel-Rahman U, Matheis G, Westphal K. Occupational exposure to inhalational anesthetics during cardiac surgery on cardiopulmonary bypass. Ann Thorac Surg. 2003;75(6):1924-7; discussion 7-8. https://doi.org/10.1016/s00034975(03)00003-1.

57. Baker RA, Bronson SL, Dickinson TA, Fitzgerald DC, Likosky DS, Mellas NB, et al. Report from AmSECT's International Consortium for Evidence-Based Perfusion: American Society of Extracorporeal Technology Standards and Guidelines for Perfusion Practice: 2013. J Extra Corpor Technol. 2013;45(3): 156-66.

58. Nigro Neto C, Landoni G, Tardelli MA. A novel anti-pollution filter for volatile agents during cardiopulmonary bypass: preliminary tests. J Cardiothorac Vasc Anesth. 2017;31(4):1218-22. https:// doi.org/10.1053/j.jvca.2016.08.009.

59. De Simone F, Cassara L, Sardo S, Scarparo E, Saleh O, Nigro Neto $\mathrm{C}$, et al. An innovative technique to improve safety of volatile anesthetics suction from the cardiopulmonary bypass circuit. Ann Card Anaesth. 2017;20(4):399-402. https://doi.org/10.4103/aca. ACA_50_17.

60. Langbein T, Sonntag H, Trapp D, Hoffmann A, Malms W, Roth EP, et al. Volatile anaesthetics and the atmosphere: atmospheric 
lifetimes and atmospheric effects of halothane, enflurane, isoflurane, desflurane and sevoflurane. Br J Anaesth. 1999;82(1): 66-73. https://doi.org/10.1093/bja/82.1.66.

61. Evans AS, Weiner MM, Arora RC, Chung I, Deshpande R, Varghese R, et al. Current approach to diagnosis and treatment of delirium after cardiac surgery. Ann Card Anaesth. 2016;19(2):32837. https://doi.org/10.4103/0971-9784.179634.

62. McPherson JA, Wagner CE, Boehm LM, Hall JD, Johnson DC, Miller LR, et al. Delirium in the cardiovascular ICU: exploring modifiable risk factors. Crit Care Med. 2013;41(2):405-13. https://doi.org/10.1097/CCM.0b013e31826ab49b.

63. Mulvey DA, Klepsch P. Use of processed electroencephalography in the clinical setting. Curr Anesthesiol Rep. 2020;10:1-8. https:// doi.org/10.1007/s40140-020-00424-3.

64. Hiraoka H, Yamamoto K, Okano N, Morita T, Goto F, Horiuchi R. Changes in drug plasma concentrations of an extensively bound and highly extracted drug, propofol, in response to altered plasma binding. Clin Pharmacol Ther. 2004;75(4):324-30. https://doi.org/ 10.1016/j.clpt.2003.12.004.

65. Mazoit JX, Samii K. Binding of propofol to blood components: implications for pharmacokinetics and for pharmacodynamics. $\mathrm{Br}$ J Clin Pharmacol. 1999;47(1):35-42. https://doi.org/10.1046/j. 1365-2125.1999.00860.x.

66. Myers GJ, Voorhees C, Eke B, Johnstone R. The effect of Diprivan (propofol) on phosphorylcholine surfaces during cardiopulmonary bypass-an in vitro investigation. Perfusion. 2009;24(5):349-55. https://doi.org/10.1177/0267659109353819.

67. Barbosa RA, Santos SR, White PF, Pereira VA, Silva Filho CR, Malbouisson LM, et al. Effects of cardiopulmonary bypass on propofol pharmacokinetics and bispectral index during coronary surgery. Clinics (Sao Paulo). 2009;64(3):215-21. https://doi.org/ 10.1590/s1807-59322009000300012.

68. Hampton WW, Townsend MC, Schirmer WJ, Haybron DM, Fry DE. Effective hepatic blood flow during cardiopulmonary bypass. Arch Surg. 1989;124(4):458-9. https://doi.org/10.1001/archsurg. 1989.01410040068015.

69. Leslie K, Sessler DI, Bjorksten AR, Moayeri A. Mild hypothermia alters propofol pharmacokinetics and increases the duration of action of atracurium. Anesth Analg. 1995;80(5):1007-14. https://doi. org/10.1097/00000539-199505000-00027.

70. Neumann FJ, Sousa-Uva M, Ahlsson A, Alfonso F, Banning AP, Benedetto U, et al. 2018 ESC/EACTS Guidelines on myocardial revascularization. Eur Heart J. 2019;40(2):87-165. https://doi.org/ 10.1093/eurheartj/ehy394.

Publisher's Note Springer Nature remains neutral with regard to jurisdictional claims in published maps and institutional affiliations. 